\title{
ALGORITHM OF TECHNICAL DIAGNOSTICS OF THE COMPLICATED DAMAGE TO THE CONTINUED RESOURCE OF THE CIRCULATION PIPELINE OF THE NUCLEAR POWER PLANT
}

\author{
H. Hrinchenko ${ }^{1}$, R. Trisch ${ }^{2}$, V. Burdeina ${ }^{3}$, S. Chelysheva ${ }^{4}$ \\ Ukrainian Engineering-Pedagogical Academy, Kharkov, Ukraine \\ E-mail: ${ }^{1}$ a.kiporenko@ukr.net; ${ }^{2}$ trich_@ukr.net; \\ ${ }^{3}$ zamorskavika@ukr.net; ${ }^{4}$ chelysheva.svitlana@gmail.com
}

The quality and safety of operation of the main circulating pipeline of the nuclear power plant is being studied in order to extend the life of the pipelines of the reactor unit of the NPP on the basis of the development of a scientifically sound mathematical model and algorithm for their technical diagnostics. The complex estimation of the quality of operation of pipeline systems is proposed, taking into account the peculiarities of their stress-strain state and seismic stability. The purpose of the article is to substantiate the integrated assessment of the quality and safety of operation of pipelines of the reactor unit of the NPP on the basis of the development of a scientifically sound mathematical model and algorithm for their technical diagnostics in order to extend the life of the operation. Research methods: calculations by mathematical model, comparison of results of calculation, forecasting of boundary parameters of technical condition and monitoring of mechanical properties of main pipeline material, inspection, qualification, determination of residual resource of buildings, structures, foundations and metal structures taking into account geotechnical and seismotectonic conditions. It is determined that in the initial period of existence of the projected residual resource seismic activity in the zone $300 . . .500 \mathrm{~km}$ from the location of the NPP is less safe than seismic activity, which takes place in the final period of the projected residual resource, as a sharp increase in the level of damage from seismic activity leads to exceeding the limit of permissible the level of damage to the material of the main pipeline.

\section{INTRODUCTION}

The problem of improving the quality, safety and lifetime of NPP power units is one of the most important and acute problems not only of nuclear power engineering but also of the whole fuel and energy complex of Ukraine. This problem can be solved only in complex, with joint and parallel solution of the tasks of extending the resource of individual elements of the equipment, taking into account their mutual influence on the reliability and durability of power units. In order to ensure safety over the project life and the quality of operation of the power unit, it is necessary to create an effective mechanism for inspection of the technical state of the base metal and welded joints of the pipeline, which would optimize the process of its operation, based on a favorable balance of economic indicators and safety. In particular, such a mechanism will enable the smooth transition to the operation of the power unit, without its long-term stop and economic losses which are associated with this, in time out of the project [1].

\section{ANALYSIS OF RECENT RESEARCH AND PUBLICATIONS}

Many of the native and foreign scientists are engaged in theoretical and experimental issues of forecasting the resource and assessing the quality of operation. In the works of native and foreign authors such as I. Fursov, G. Belkin, Y. Golodnov, S. Lizunov, V. Strelnikov, P. Svi, S. Polischuk, G. Kanyuk, M. Girya, R. Hall, J.H. Taylor, J.I. Boccio, on the basis of research and own experience, is recommended to use modern methods and methods of control and diagnostics to assess the technical condition, but the estimates are considered outside the context of the continuation of the resource of mechanical equipment. The existing regulatory framework for the safe operation of NPP, including design standards (DS) 306.2.099-2004, DS 306.2.106-2005, DS 306.2.141-2008 etc. They contain the basic criteria and requirements for safety of equipment of the NPP in the established period of operation, but does not regulate the conduct of complex analysis of the quality of equipment, because they do not take into account changes in technical characteristics and parameters during its operation, different degrees of lifetime due to the influence of operational and regime conditions [2].

\section{SELECTION OF PREVIOUSLY UNSETTLED PARTS OF THE GENERAL PROBLEM}

Further scientific and mathematical reasoning requires an assessment of the quality of operation and technical condition of the equipment, namely: analysis of technical documentation, expert examination, analysis of the aging mechanism, refinement of the boundary states and their criteria, calculation of stressed-deformed state, calculation of strength, which will allow the extension of the term service of NPP power units.

The purpose of the article is to substantiate the integrated assessment of the quality and safety of operation of pipelines of the reactor unit of the NPP on the basis of the development of a scientifically sound mathematical model and algorithm for their technical diagnostics in order to extend the life of the operation. To offer a comprehensive assessment of the quality of operation of pipeline systems, taking into account the features of their stress-strain state and seismic resistance. 
In order to achieve this goal, it is necessary to create an algorithm for a comprehensive assessment of the quality and safety of operation, in the presence of accelerated processes of wear of pipelines of the reactor unit of the NPP based on the following mechanisms of accumulation of damage:

1) to analyze the statistical data on the reliability and efficiency of the equipment;

2) to create data bases of groups and equipment elements, their ranking according to the degree of criticality;

3) to develop quality criteria and methods for determining the residual resource;

4) to examine, qualify, determine the residual life of buildings, structures, foundations and metal structures taking into account geotechnical and seismotectonic conditions;

5) to develop methods for optimizing operating modes of equipment in order to reduce the rate of damage (resource consumption rate) of critical elements of equipment;

6) to develop methods of technical diagnostics, control and monitoring of the technical condition and equipment remaining equipment.

\section{THE PRESENTATION OF THE MAIN MATERIAL}

The quality and safety of the power unit depends on the technical condition of all its power systems, both main and backup. One of the main power unit systems is piping systems, the technical condition of which is determined by the quality of all elements, namely the linear part, the pump equipment and the spare part. The most important factors determining the technical condition are: duration of operation, steel stamp of the pipeline, actual operating regimes, corrosion activity of the coolant (water, steam), frequency of periodic tests with high pressure, internal pressure in the pipeline, temperature and composition of the coolant, weight load (supports, fasteners), vibration load.

Changing the technical state of the metal pipelines as a result of deterioration of mechanical properties arises due to:

- the appearance and development of corrosion defects in the metal pipeline;

- nucleation and growth of tidal cracks in places of concentration of voltage, defects from tidal and low cyclic loading;

- extinction and cracking of metal pipelines as a result of vibration load.

According to the purpose of the work, the mechanisms of accumulation of damage are factors that arise as separate mechanisms of accumulation of damage, but, as a rule, they are mixed. The presence of one of the destructive factors leads to the strengthening of others. Thus, for assessing the technical condition and forecasting of the resource of piping systems, an algorithm for a comprehensive assessment of the quality and safety of operation is proposed, taking into account a complex of mechanisms of accumulation of damage, which consists of several stages.

The first stage. It is necessary to construct a three dimensional (shell) model of the pipeline and define the control areas of the metal on straight and bent sections. This makes it possible to determine the stresses arising from the external and internal sides of the pipeline walls (Fig. 1).

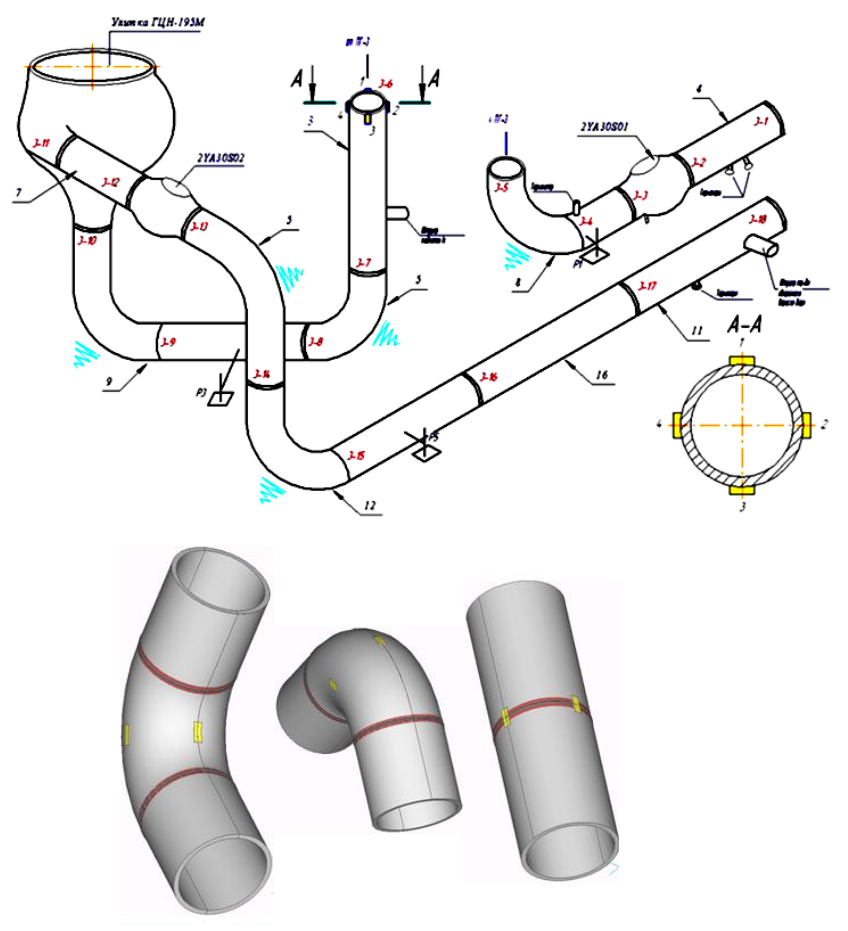

Fig. 1. Model of the main circulating pipeline and control circuits for typical pipeline sections

The second stage. Determine the actual load under different operating conditions: NOC - normal operating conditions; VNOC - violation of normal operating conditions; HT - hydraulic tests. The construction of the load unit, taking into account the low cycle and vibration load, allows us to estimate the stress-strain state of the pipeline and is the starting point for calculating the actual cyclic loads of $N_{i}$ over the lifetime. According to the load diagram, the cyclic strength of the main circulating pipeline is considered to be secured if, in the presence of various cyclic loads $N_{i}$, the condition:

$$
\sum_{i=1}^{k} \frac{N_{i}}{\left[N_{0}\right]_{i}}=a \leq\left[a_{N}\right],
$$

where $a$ is an accumulated fatigue damage to equipment and pipelines from load operation cycles; $\left[a_{N}\right]$ is a permissible value of accumulated fatigue damage, $\left[a_{N}\right]=1 ;\left[N_{0}\right]_{i}$ is allowable number of load cycles. The actual number of cycles is determined by constructing a load block with a note of the operating parameters of the pressure $\mathrm{P}_{\mathrm{i}}$ and the corresponding pressure differences $\Delta \mathrm{P}_{\mathrm{i}}$. If there are several modes, then the accumulated fatal damage to the equipment and pipelines from load operation cycles is determined by:

$$
a=\frac{N_{N O}}{\left[N_{0}\right]_{N O}}+\frac{N_{V N O}}{\left[N_{0}\right]_{V N O}}+\frac{N_{H T}}{\left[N_{0}\right]_{H T}},
$$

where $\left[N_{0}\right]_{N O},\left[N_{0}\right]_{V N O},\left[N_{0}\right]_{H T}-$ the number of cycles that can withstand the pipeline in load mode NO, VNO, HT, respectively; $\left[N_{0}\right]_{N O},\left[N_{0}\right]_{V N O},\left[N_{0}\right]_{H T}$. 
The combination of the main cyclic load with amplitude $\left(\sigma_{\mathrm{A}}\right)$ frequency $f_{0}$ and frequency $f$, which is imposed with the amplitude $\left\langle\sigma_{\mathrm{a}}\right\rangle$, causes a decrease in the admissible number of basic low frequency load cycles, which is proposed to take into account the input coefficient $\aleph$ - the coefficient of reduction of durability in the application of high frequency cycles. The coefficient $\aleph$ is determined by the formula:

$$
\aleph=\left(\frac{f}{f_{0}}\right)^{\eta \frac{\left\langle\sigma_{a}\right\rangle}{\left(\sigma_{a}\right)}},
$$

where $f_{0}=1 /\left(t_{1}+t_{2}\right)$ is the frequency of the main cycle of variable stresses, which is determined without taking into account the period of time during which there is an overlay of additional stresses on the constant, $\mathrm{hz} ; t_{1}$ is transition time, hours; $t_{2}$ is fixed working time, hours; $\left\langle\sigma_{\mathrm{a}}\right\rangle$ is amplitude of the given stresses of the vibrational component of the cycle, $\mathrm{MPa}\left(\mathrm{kgf} / \mathrm{mm}^{2}\right) ;\left(\sigma_{\mathrm{a}}\right)$ is amplitude of the given stresses of the main cycle without the concentration of stress, $\mathrm{MPa}\left(\mathrm{kgf} / \mathrm{mm}^{2}\right) ; \eta$ is a coefficient depending on the material (normative parameter is chosen according to Rules and norms in atomic energy 7-002-86) [3]. The main load cycle of the damage $a_{3}^{*}$ is determined by the formula:

$$
\left(a_{3}^{*}\right)_{i}=\aleph_{i} N_{i} /\left[N_{0}\right]_{i} \text {. }
$$

To verify the fulfillment of this condition, it is necessary to determine how the permissible number of load cycles $\left[N_{0}\right]_{i}$ when mechanical properties change, and the actual cyclic loads of different types of $N_{i}$. The total (permissible) number of cycles $\left[N_{0}\right]_{i}$ to fracture consists of two terms: $N_{3}$ is the number of cycles to the origin of the defect, $N_{p}$ is the number of cycles at the stage of development of the defect.

$$
\left[N_{0}\right]_{i}=N_{3}+N_{P} \text {. }
$$

The number of cycles before the defect is generated by the Coffin-Manson equation. With the help of this equation, we establish the relationship between the amplitude of the deflection deformation, the mechanical properties of the metal and the number of cycles $N_{3}$.

Third stage. To determine the actual mechanical properties of the metal pipeline and its geometric dimensions to determine the most dangerous from the point of view of the integrity of the pipelines, for which the greatest loads and impacts are possible. The minimum values of current mechanical properties and their values of wall thickness were determined by the results of thickness measurement, and the radii of curvature were selected according to the executive diagrams and work drawings. Since there are two load modes, a rigid (with a constant magnitude of deformation values) and a soft (with a constant magnitude of voltage values), then this fact needs to be taken into account when determining $N_{3}$. Also, load modes are distinguished by symmetry, which is proposed to be taken into account by means of determining the coefficient of asymmetry: by stress $\mathrm{R}_{\sigma}=\sigma_{\text {min }} / \sigma_{\text {max }}$ and deformation $R_{\mathrm{e}}=e_{\text {min }} / e_{\text {max }}$, that is, the ratio of the corresponding indicators at minimum and maximum loads in the cycle. For a rigid symmetric loading regime, the number of cycles before the defect is generated is determined from the equation:

$$
N_{3}=\sqrt[x_{1}]{\frac{\ln \frac{1}{1-Z}}{4\left(e_{a}-\frac{\sigma_{-1}}{E}\right)}},
$$

where $e_{a}$ - the amplitude of the actual deformations at the top of the defect, $\mathrm{MPa}\left(\mathrm{kgf} / \mathrm{mm}^{2}\right) ; \mathrm{Z}$ is relative narrowing, $\% ; \chi_{1}$ is rigid cyclic load index; $\sigma_{-1}$ is limit of fatigue of a metal with symmetrical loading, $\operatorname{MPa}\left(\mathrm{kgf} / \mathrm{mm}^{2}\right): \quad \sigma_{-1}=0.4 R_{m} ; E$ is modulus of elasticity, MPa $\left(\mathrm{kgf} / \mathrm{mm}^{2}\right)$. Indicator $\chi_{1}$ is determined depending on the strength of the metal:

$$
\chi_{1}=0.5 \text { at } R_{m} \leq 700 \mathrm{MPa} ;
$$

$\chi_{1}=0.5+0.0002\left(R_{m}-700\right)$ at $R_{m}>700 \mathrm{MPa}$.

For a soft symmetric loading regime, the number of cycles is determined from the equation:

$$
N_{3}=\sqrt[x]{\frac{\ln \frac{1}{1-Z}}{4\left(e_{a}-\frac{\sigma_{-1}}{E}\right)}},
$$

where $\chi_{2}$ is is the index of soft cyclic loading, which is determined by the formula:

$$
\chi_{2}=1.2 \frac{R_{0.2}}{R_{m}}-0.35 \text {. }
$$

In order to determine the number of cycles with asymmetric load it is proposed to take into account the asymmetry of the cycle by deformation by determining an equivalent load:

$$
\tilde{\mathrm{e}}_{a}=\frac{e_{a}}{1-e_{a v} / e_{\mathrm{K}}}
$$

where $e_{k}$ is maximum deformation to crack formation at the top of the defect, MPa $\left(\mathrm{kgf} / \mathrm{mm}^{2}\right) ; e_{a}$ is amplitude of deformation at the peak of the defect, $\mathrm{MPa}$ $\left(\mathrm{kgf} / \mathrm{mm}^{2}\right) ; e_{a v}$ is average deformation at the same point, $\mathrm{MPa}\left(\mathrm{kgf} / \mathrm{mm}^{2}\right)$. The values of $e_{a}$ and $e_{c p}$ for formula (7) are determined as follows:

$$
e_{a v}=e_{\max }+e_{\min } / 2 ; e_{a}=\left(e_{\max }-e_{\min }\right) / 2,
$$

where $e_{\max }, e_{\min }-$ respectively, the smallest and largest deformation in the process of cyclic change in pressure (voltage), $\mathrm{MPa}\left(\mathrm{kgf} / \mathrm{mm}^{2}\right)$. On the basis of the definition $\tilde{e}_{a}$ and by adding its value, instead of the value of the amplitude of the actual deformations at the vertex of the defect $\left(e_{a}\right)$, by formulas (5) and (7), we determine the number of cycles for hard (9) and soft (10) asymmetric loaded, respectively: 


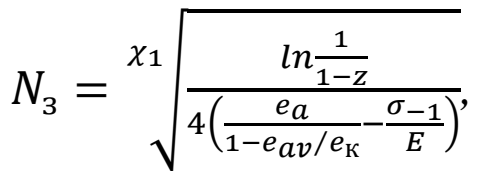

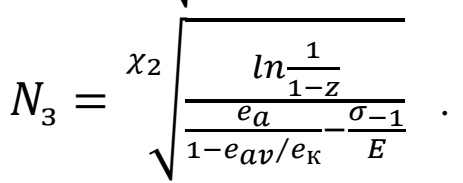

The number of cycles at the stage of development of a defect with cyclic loaded $N_{p}$ is determined by the formula:

$$
N_{p}=\int_{l_{0}}^{l c} \frac{d a}{c_{e}\left(K_{I e}\right)^{n_{e}}}
$$

where $l_{C}$ is the critical depth of the defect satisfying the condition $K_{\mathrm{I} e}=0.8 K_{I e C}, \mathrm{~m} ; l_{0} K_{I e}=0.8 \cdot K_{I e C}, l_{0}-$ initial data of the depth of the defect, $\mathrm{m}$; $d a$ is growth rate of the crack, $\mathrm{m} /$ cycle; $C_{e}, n_{e}$ - parameters of fracture resistance of the metal pipeline; $K_{I e}$ is intensity of stresses, MPa $\left(\mathrm{kgf} / \mathrm{mm}^{2}\right)$. The intensity of the stresses is proposed to be calculated taking into account the geometry of the defect [4]. The calculation of the stress intensity factor for an elliptic surface crack (Fig. 2) at points $\mathrm{A}$ and $\mathrm{B}$ is determined by the following formulas:

$$
\begin{aligned}
& K_{I A}=M_{A} N_{A} S_{A} \sqrt{\frac{\pi l}{Q}}, \\
& K_{I B}=M_{B} N_{B} S_{B} \sqrt{\frac{\pi l}{Q}}, \\
& Q=1+1.464 \alpha^{1.65},
\end{aligned}
$$

where $N_{A}=\left[1-(0.89-0.57 \sqrt{\alpha})^{3} \tau^{1.5}\right]^{-3.25}$, $M_{A}=1.12-0.08 \alpha$ is a crack parameter at point A, m; $N_{B}=\left(1+0.32 \tau^{2}\right) N_{A} ; M_{B}=(1.23-0.09 \alpha) \sqrt{\alpha}$ is a crack parameter at point $\mathrm{B} ; l$ is a crack depth, $\mathrm{m} ; c$ is a width of the crack, $\mathrm{m} ; \alpha=l / c$ at $l \leq c ; r=l / t$ at $l \leq 0.7 t$.
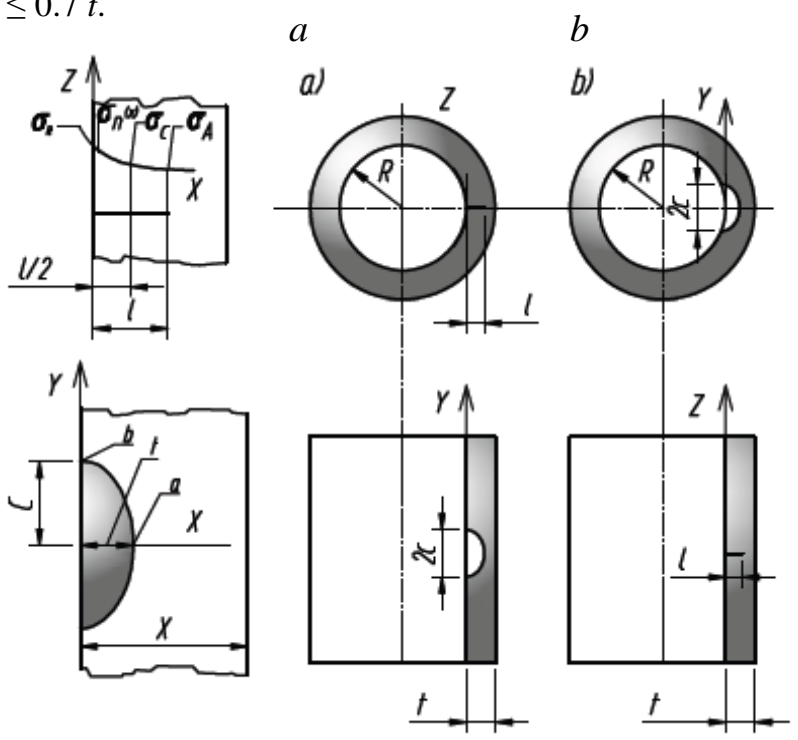

Fig. 2. The scheme of a surface semi-elliptic fracture with a curvature on the surface:

$a$-along the axis $Z ; b$-along the $Y$ axis

Changes in the mechanical properties of the metal pipeline were taken into account with the help of the following functions:

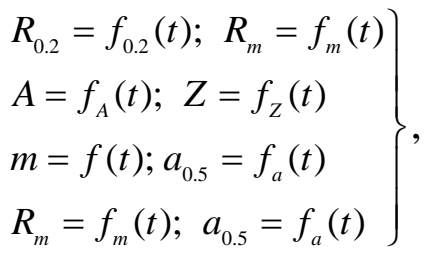

where is operating time, years; $f_{0.2} \ldots f_{m}$ is empirical function.

Mechanical properties of the metal of the main circulation pipe

\begin{tabular}{|c|c|c|c|c|c|c|c|}
\hline Pipeline area & Hardness & $\begin{array}{c}R_{\mathrm{m}}^{\mathrm{T}} \\
\mathrm{MPa}\end{array}$ & $\begin{array}{c}R_{\mathrm{p} 0.2}^{\mathrm{T}}, \\
\mathrm{MPa}\end{array}$ & $\begin{array}{c}Z^{\mathrm{T}}, \\
\%\end{array}$ & $A^{\mathrm{T}}, \%$ & $\begin{array}{c}\text { Thickness, } \\
\mathrm{mm}\end{array}$ & $\begin{array}{c}\text { Radius of } \\
\text { curvature, } \\
\mathrm{mm}\end{array}$ \\
\hline $\begin{array}{c}\text { Main circulating pipeline } \\
\text { ("hot” thread) }\end{array}$ & 167.6 & 55.10 & 41.79 & 66.67 & 27.64 & 78.29 & 495.0 \\
\hline $\begin{array}{c}\text { The main church pipeline } \\
\text { («cold» thread, section from Steam } \\
\text { Generator till Cerculating pump }\end{array}$ & 168.0 & 55.28 & 41.91 & 66.60 & 27.55 & 78.45 & 495.0 \\
\hline $\begin{array}{c}\text { Main circulating pipeline (“cold” } \\
\text { thread), section from main Cerculating } \\
\text { pump till hydraulic pump) }\end{array}$ & 181.0 & 61.26 & 46.01 & 64.33 & 24.92 & 108.2 & 495.0 \\
\hline $\begin{array}{c}\text { Pipeline connection collector with hot } \\
\text { thread of a loop No.4 Main } \\
\text { Circulation Circuit }\end{array}$ & 168.4 & 55.46 & 42.04 & 66.53 & 27.46 & 39.98 & 213.0 \\
\hline
\end{tabular}


In Table provided mechanical properties of the HCT metal and the communication line collector with the "hot" thread loop No.4 Main Circulation Circuit and geometric sizes of sites.

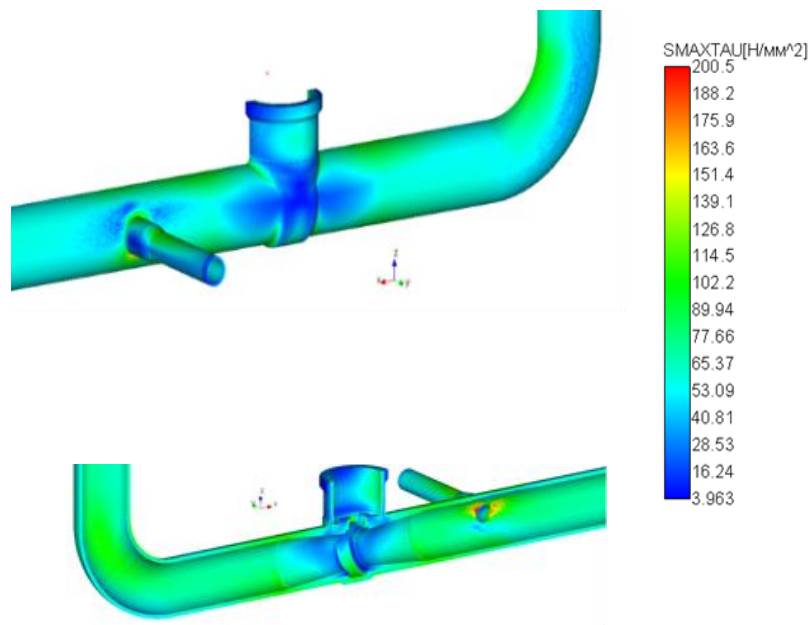

Fig. 3. Distribution of stresses $\sigma_{1-3}$ at the section of the pipeline Main circulating pipeline, "hot" thread.

(Mode -NO, load - internal pressure)
Fourth stage. To conduct a calculation of stress distribution in the pipeline (Fig. 3) depending on the operating mode: NO, HT [5].

The fifth stage. To establish the correspondence between the parameters of the technical condition and the strength conditions $[\mathrm{P}]$ of the pipelines in accordance with the rules Norms of strength calculation equipment [3].

The sixth stage. To determine the regularities of changing the properties of the metal pipeline during operation using the analysis of operational changes in mechanical properties of the metal $R_{\mathrm{m}}^{\mathrm{T}}, R_{\mathrm{p} 0,2}^{\mathrm{T}}, Z^{\mathrm{T}}, A^{\mathrm{T}}$, $K_{\mathrm{IC}}$, and so on (see Fig. 3). To conduct a calculation on the resistance to brittle fracture of the elements. The mathematical models of the accumulation of fatigue damage of equipment and pipelines from load operation cycles in hard (19) and soft (20) symmetrical loading modes, in hard (21) and soft (22) asymmetric loading modes are proposed, taking into account the geometry of the defect and changes in the mechanical properties of the metal pipeline:

$$
\begin{aligned}
& \left(a_{3}^{\bullet}\right)_{i}=f\left(\frac{f}{f_{o}}\right)_{i}^{\eta \frac{\left(\sigma_{a}\right)}{\left(\sigma_{a}\right)}} \cdot N_{i} /\left(\sqrt[x_{1}]{\frac{\ln \frac{1}{1-z}}{4\left(e_{a}-\frac{\sigma_{-1}}{E}\right)}}\right)_{i}+\left(\int_{l o}^{l c} \frac{d a}{c_{e}\left(K_{1 e}\right)^{n_{e}}}\right)_{i}, \\
& \left(a_{3}\right)_{i}=f\left(\frac{f}{f_{o}}\right)_{i}^{\eta \frac{\left(\sigma_{a}\right)}{\left(y_{a}\right)}} \cdot N_{i} /\left(\sqrt[x_{2}]{\frac{\ln \frac{1}{1-z}}{e_{a}-\frac{\sigma_{-1}}{E}}}\right)_{i}+\left(\int_{l o}^{l c} \frac{d a}{c_{e}\left(K_{1 e}\right)^{n_{e}}}\right)_{i}, \\
& \left(a_{3}^{*}\right)_{i}=\left(\frac{f}{f_{0}}\right)^{\eta \frac{\left\langle\sigma_{a}\right\rangle}{\left(\sigma_{a}\right)}} N_{i} /\left(\chi_{1} \sqrt{\frac{\ln \frac{1}{1-z}}{4\left(\frac{e_{a}}{1-e_{a v} / e_{\mathrm{K}}}-\frac{\sigma_{-1}}{E}\right)}}\right)_{i}+\left(\int_{l_{0}}^{l_{c}} \frac{d a}{C_{e}\left(K_{\mathrm{I} e}\right)^{n_{\mathrm{e}}}}\right)_{i} \\
& \left(a_{3}^{*}\right)_{i}=\left(\frac{f}{f_{0}}\right)^{\eta \frac{\left\langle\sigma_{a}\right\rangle}{\left(\sigma_{a}\right)}} N_{i} /\left(\chi_{2} \sqrt{\frac{\ln \frac{1}{1-z}}{1-e_{a v} / e_{\mathrm{K}}}-\frac{\sigma_{-1}}{E}}\right)_{i}+\left(\int_{l_{0}}^{l_{c}} \frac{d a}{C_{e}\left(K_{\mathrm{I} e}\right)^{n_{\mathrm{e}}}}\right)_{i}
\end{aligned}
$$

The seventh stage. Forecasting of the limit parameters of the technical state of the pipelines under which the conditions of durability are not violated $\mathrm{P}_{\lim }=$ $[\mathrm{P}]_{\text {lim. }}$. At this stage, data from the results of stages 5 and 6 and dependency forecasting are used $[\mathrm{P}](\tau)$ and $\mathrm{P}(\tau)$ taking into account the requirements of normative documents [6] to the limit parameters of the pipelines (Fig. 4).

To take into account the results of stages 5 and 6 and forecast dependencies $[\mathrm{P}](\tau)$ and $\mathrm{P}(\tau)$ it is necessary to add a condition. The figure follows the following. The design documentation was planned at the level with the loads, as well as the levels of radiation exposure and vibration of the mechanisms and machines of the nuclear power plant. This aggregate level of coercive damage was introduced at design (dependence 1), which was supposed to reduce the strength of the material of the main pipeline by the dependence 2 over a period of time from $t_{0}$ till $t_{1}$ from mark $\mathrm{A}$ to mark $\mathrm{B}_{1}$ ie up to level $\mathrm{P}_{\text {lim }}=[\mathrm{P}]_{\text {lim }}$ line 3 .

In reality, the strength indicators for the time interval from $t_{0}$ till $t_{1}$ dropped to the level $B_{2}$. According to the dependence 4 , the reduction of the material strength of the main pipeline, along the axis of ordinates, from $t_{0}$ till $t_{1}$ decreased to magnitude $A$. After this, we have a total residual resource for strength $\left(R_{\sigma}\right)$ at the level:

$$
R_{\sigma}=B_{2}-B_{1}
$$




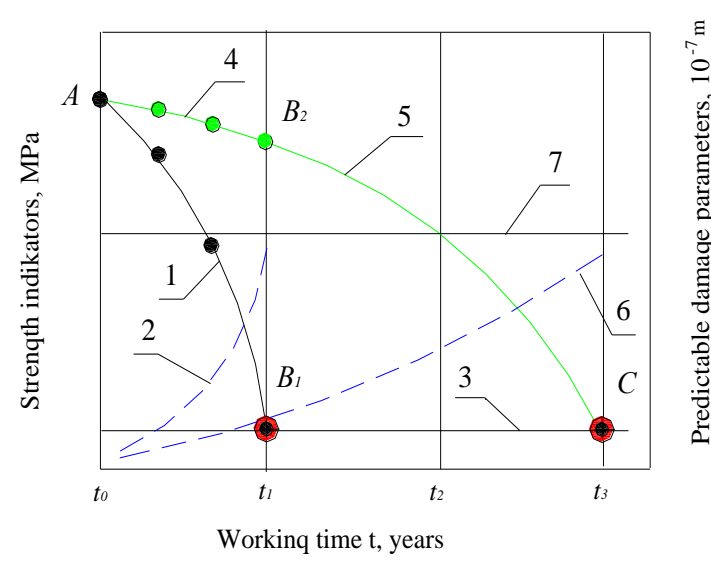

Fig. 4. Scheme of total impact on the material of the main pipeline of the NPP, the power of the working fluid body, radiation and vibration of mechanisms and machines

The extrapolation of the strength of the material of the main pipeline has shown that the level of marginal strength $\left[\mathrm{P}_{\text {lim }}\right]$, indicated by the straight 3 material will reach at $\mathrm{D}$. This means that we have a predicted residual time resource $t_{R}$, which is defined as follows:

$$
t_{R}=t_{3}-t_{1},
$$

where $t_{3}$ is projected time when the strength of the main pipeline material is reduced to a level of ultimate strength $\left[\mathrm{P}_{\text {lim }}\right], \mathrm{MPa} ; t_{l}$ is the time at which, according to the design calculations, should have fallen to the level of marginal strength $\left[\mathrm{P}_{\text {lim }}\right], \mathrm{MPa}$. This is likely to happen only for two reasons, firstly, the actual level of radiation exposure (see Fig. 4, dependence 5) was significantly lower than expected, and secondly, the properties of the resistivity of the main pipeline material were significantly higher than expected (dependence 4).

Thus, the complex estimation of the calculations we accept the level of damage (deviation of the size) of the material of the main pipeline (see Fig. 4, dependence 6). From Fig. 4 it follows that it is possible to operate a nuclear power plant because the current value of damage during the time interval from $t_{1}$ to $t_{3}$ is beyond the level of the limit values, the boundary of which is on line 7 (see Fig. 4). The condition for safe subsequent operation of the NPP is the reduction of the permissible load on the material of the main pipeline in the time interval from $t_{2}$ to $t_{3}$.

The eighth stage. To conduct an assessment and justification for conducting settlement investigations of seismic influences on NPP equipment for safe operation during a project earthquake and a maximum calculated earthquake [7]. In Ukraine, the seismic environment is attractive for the construction of a nuclear power plant, but the earthquakes that took place in Romania and Moldova in 1986, 1990, and in October 2018, affect the seismic situation in Ukraine. In addition, the vibration of mechanisms and machines on the NPP itself constantly causes a slight but permanent damage to the main pipeline of the NPP. In addition, at such plants as the NPP, the material of the main pipeline constantly has a certain level of radiation exposure. Therefore, combine the destructive effect of radiation irradiation, the effect of vibration of mechanisms and machines, and the effect of liquid pressure on the material of the main pipeline NPP mean dependence 4 (Fig. 5).

In this work, the mathematical model of the accumulation of fatigue damage to equipment and pipelines from load operation cycles during hard (16) and soft (17) symmetrical loading modes, with hard (18) and soft (19) asymmetric load modes taking into account the geometry of the defect and the mechanical properties of the metal pipeline. According to the results of the research, the dependence of the damage to the main pipeline of the NPP during load operating cycles under conditions of strict symmetric loading regime and with additional influence of the project earthquake and with the maximum calculated earthquake were constructed (see Fig. 5).

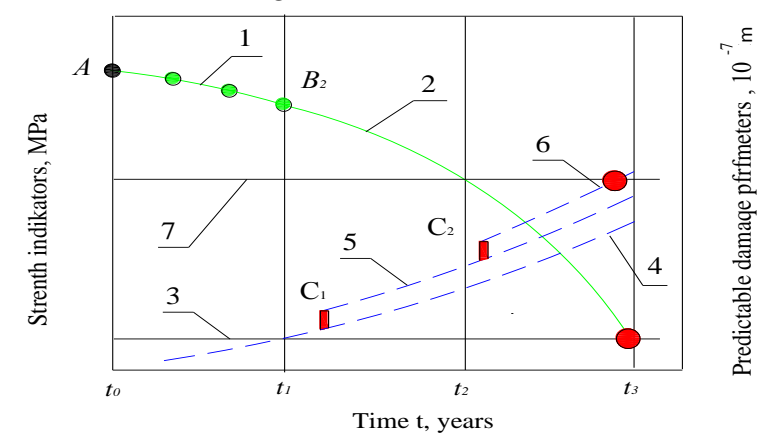

Fig. 5. Impact of seismic situations on NPP equipment damage

From Fig. 5, it follows that in other equal conditions (that is, in the presence of the projected residual resource for the strength of the material of the main pipeline), the level of its damage in the rigid mode of loading, taking into account the average speed of the defect and the average mechanical properties of the metal of the pipeline (interval of time from $t_{1}$ to $t_{3}$ ) dependence 4 (see Fig. 5). Curves 5 and 6 were also constructed, which show the effect of additional seismic activity on damage to the material of the main pipeline. Thus, it was determined that after the first seismic activity the dependence of the damage from time to time was changed by the dependence 5, and after the second seismic activity by the dependence 6. From Fig. 5 also suggests that less safer seismic activity takes place in the initial period of existence of the projected residual resource, and in the final period of the projected residual resource, seismic activity is dangerous, as a sharp increase in the level of damage from seismic activity leads to exceeding the limit of permissible level of damage to NPP equipment.

\section{CONCLUSIONS AND PERSPECTIVES OF FURTHER RESEARCH}

As a result of the conducted research, the following conclusions can be drawn that a comprehensive solution to the problem of quality improvement and extension of the lifetime of power units should begin with the implementation of over-design works in the following areas: analysis of statistical data on the reliability and efficiency of equipment operation; creation of databases of groups and elements of equipment, their ranking according to the degree of criticality; development of criteria for quality and methods for determining the 
residual resource; examination, qualification, definition of residual resource of buildings, structures, foundations and metal structures taking into account geotechnical and seismotectonic conditions; development of methods for optimizing operating modes of equipment in order to reduce the rate of damage (resource consumption rate) of critical elements of equipment; development of methods for technical diagnostics, monitoring and monitoring of the technical condition and the remaining resource of equipment.

\section{REFERENCES}

1. Г.С. Кіпоренко, М.С. Пахалович, О.М. Хорошилов. Оцінка технічного стану трубопровідних систем AEC на відповідність нормативним параметрам // Системи управління, навігащіï та зв'язку. 2016, №4, с. 146-152.

2. М.Є. Пахалович, Г.С. Кіпоренко. Вдосконалення методики розрахунку опору крихкому руйнуванню трубопроводів Південно-Української
АЕС // Системи обробки інформаџіï. 2016, №7, c. 181-184.
3. ПНАЭ Г-7-002-86. Нормы расчета на прочность оборудования и трубопроводов атомных энергетических установок.

4. Г.С. Кіпоренко. Удосконалення нормативного забезпечення експлуатаційної безпеки трубопровідних систем атомних електростаниій: Автореф. дис. ... канд. техн. наук. Харків: Українська інженерно-педагогічна академія, 2010, 20 с.

5. П.Н. Демидов, А.И. Трубаев. Прогнозирование остаточного ресурса трубопроводов с учетом эрозионно-коррозионного износа // Вісник HТУ «ХПI». 2011, №12, c. 23-31.
6. СОУ НАЕК 033:2012. Техническое обслуживание и ремонт. Правила организаџии технического обслуживания и ремонта систем $u$ оборудования атомных электростанций.

7. ПНАЭ Г-5-006-87. Нормы проектирования сейсмостойких атомных станций.

\section{АЛГОРИТМ ТЕХНИЧЕСКОЙ ДИАГНОСТИКИ КОМПЛЕКСА НАКОПЛЕННЫХ ПОВРЕЖДЕНИЙ ДЛЯ ПРОДЛЕНИЯ РЕСУРСА ЦИРКУЛЯЦИОННОГО ТРУБОПРОВОДА АЭС}

\section{А. Гринченко, Р. Трищ, В. Бурдейная, С. Челищева}

Исследуются качество и безопасность эксплуатации главного циркуляционного трубопровода атомной электростанции с целью продления ресурса трубопроводов реакторного отделения АЭС на основе разработки научно обоснованной математической модели и алгоритма их технической диагностики. Предложена комплексная оценка качества эксплуатации трубопроводных систем путем учета особенностей их напряженно-деформированного состояния и сейсмостойкости. Целью статьи является обоснование комплексной оценки качества и безопасности эксплуатации трубопроводов реакторного отделения АЭС на основе разработки научно обоснованной математической модели и алгоритма их технической диагностики с целью продления срока эксплуатации. Методы исследования: расчеты с помощью математической модели; сравнение результатов вычисления, прогнозирования предельных параметров технического состояния и мониторинг механических свойств материала магистрального трубопровода; обследование, квалификация, определение остаточного ресурса зданий, сооружений, фундаментов и металлоконструкций с учетом геотехнических и сейсмотектонических условий. Определено, что в начальный период существования прогнозируемого остаточного ресурса сейсмическая активность в зоне $300 \ldots 500$ км от расположения АЭС менее безопасная, чем сейсмическая активность, которая проходит в заключительный период прогнозируемого остаточного ресурса, так как резкое повышение уровня повреждения от сейсмической активности приводит к превышению предела допустимого уровня повреждения материала магистрального трубопровода.

\section{АЛГОРИТМ ТЕХНІЧНОЇ ДІАГНОСТИКИ КОМПЛЕКСУ НАКОПИЧЕНИХ ПОШКОДЖЕНЬ ДЛЯ ПОДОВЖЕННЯ РЕСУРСУ ЦИРКУЛЯЦЙНОГО ТРУБОПРОВОДУ АЕС}

\section{Г. Грінченко, Р. Тріщ, В. Бурдейна, С. Челишева}

Досліджуються якість та безпека експлуатації головного циркуляційного трубопроводу атомної електростанції з метою подовження ресурсу трубопроводів реакторного відділення АЕС на основі розробки науково обгрунтованої математичної моделі та алгоритму їх технічної діагностики. Запропоновано комплексну оцінку якості експлуатації трубопровідних систем шляхом врахування особливостей їх напружено-деформованого стану та сейсмостійкості. Метою статті є обгрунтування комплексної оцінки якості та безпеки експлуатації трубопроводів реакторного відділення АЕС на основі розробки науково обгрунтованої математичної моделі та алгоритму їх технічної діагностики з метою продовження терміну експлуатації. Методи дослідження: розрахунки за допомогою математичної моделі; порівняння результатів обчислення, прогнозування граничних параметрів технічного стану та моніторинг механічних властивостей матеріалу магістрального трубопроводу; обстеження, кваліфікація, визначення залишкового ресурсу будівель, споруд, фундаментів і металоконструкцій з урахуванням геотехнічних і сейсмотектонічних умов. Визначено, що в начальний період існування прогнозованого залишкового ресурсу сейсмічна активність у зоні 300...500 км від розташування АEC $є$ менш безпечніша, ніж сейсмічна активність, яка проходить у завершальний період прогнозованого залишкового ресурсу, так як різке підвищення рівня пошкодження від сейсмічної активності призводить до перевищення межі допустимого рівня пошкодження матеріалу магістрального трубопроводу. 